\title{
Enforcing Tax Compliance: To Punish or Persuade?
}

\author{
Kristina Murphy* \\ Faculty of Arts and Education \\ Deakin University \\ (email: tina.murphy@deakin.edu.au)
}

\begin{abstract}
A long standing debate has existed between those who believe deterrence-based enforcement strategies work for gaining compliance from offenders and those who believe gentle persuasion and cooperation is more effective. This article is concerned with the issue of how to best deal with offenders so as to increase support for the law and lower the rate of subsequent re-offending. Using survey data from 652 taxpayers who have been through an enforcement experience with the Australian Taxation Office, the present study will show that depending on how an enforcement experience is perceived by offenders (as either stigmatic or reintegrative in nature) can influence the feelings of resentment they experience, but more importantly these feelings of resentment mediate the effect of punishment on subsequent compliance behaviour. In other words, it is these feelings of resentment in response to disapproval that go on to predict who will and will not comply with their subsequent obligations under the law.
\end{abstract}

\section{INTRODUCTION}

Determining which regulatory enforcement strategy will be the most effective in gaining longterm voluntary compliance from taxpayers is a challenge for all tax authorities around the world. A long-standing debate in the regulatory literature has been between those who think that individuals will comply with rules and regulations only when confronted with harsh sanctions and penalties, and those who believe that gentle persuasion and cooperation works in securing compliance (see Ayres and Braithwaite 1992). These two alternative approaches to enforcement have been termed the 'deterrence' and 'accommodative' models of regulation, respectively. The deterrence model has tended to dominate policy-making and enforcement approaches in taxation. But is this approach the most effective in nurturing long-term compliance with the law? This article is concerned with the issue of how to deal with offenders so as to increase support for the law and lower the rate of subsequent re-offending.

Using survey data collected from 652 tax offenders who have been caught and punished by the Australian Taxation Office (ATO) for engaging in illegal tax avoidance schemes, this study will show that enforcement approaches that rely on a punitive deterrence-based strategy run the risk of alienating tax offenders from both the tax system and the authority enforcing

* The present research was supported by a Discovery Grant from the Australian Research Council (DP0666337). 
the law, which in turn can have a negative long-term effect on their compliance behaviour. In contrast, it will be shown that enforcement strategies that are perceived to be fair, respectful, and reintegrative in nature have a positive impact on long-term compliance behaviour. Before presenting the findings in detail, this article will first begin with a discussion of the deterrence and accommodative models of regulation, and their application to taxation. The article will then proceed to offer a possible theoretical explanation for why a deterrence-based enforcement approach may be counterproductive and why an accommodative approach may be more fruitful in the long-term.

\section{Deterrence versus Accommodative Enforcement Models}

The deterrence doctrine can be traced back to the classic works of Jeremy Bentham and Cesare Beccaria (Beccaria 1797, Bentham 1788). The basic premise of their classic utilitarian theory of crime is that people are rational actors who behave in a manner that will maximise their expected utility. In other words, individuals assess opportunities and risks and disobey the law when the anticipated fine and probability of being caught are small in relation to the profits to be made through non-compliance. The view is that if an individual is a rational decision maker whose aim is to maximise expected utility, regulatory authorities should respond by deterring them from acts of non-compliance by ensuring the benefits to be obtained through non-compliance are lower than those obtained through compliance. It was suggested by Becker (1968) that this could be achieved in one of two ways: a) by increasing the chances of detecting non-compliers; and b) by increasing sanctions to the point where non-compliance becomes irrational. Becker (1968, p. 208) argued that authorities needed to find an appropriate balance between these two measures to make compliance behaviour the rational choice.

It was in the late 1960s that researchers became particularly interested in researching the effects of deterrence on compliance with laws. And indeed, a number of researchers reported inverse relationships between the threat of legal punishment and the volume of crime (e.g., Gibbs 1968, Jensen 1969, Tittle 1969). Both Gibbs (1968) and Tittle (1969) reported evidence of a relationship between the certainty of legal sanctions and crime rates, and Jensen (1969) reported evidence of a relationship between perceived risk of legal sanctions and self-reported delinquency levels.

In the early 1970s, Allingham and Sandmo (1972) extended Becker's work on the economics of crime to the taxation context. Like in the Becker model, Allingham and Sandmo built their model around the premise of the utility maximising individual. They examined taxpayers' decision to evade taxes when they were filling out their tax returns, and examined the relationship between the penalty rate for tax evasion at the time, the probability of detection, and degree of tax evasion engaged in. What they found was that there was a relationship between these variables; with a higher penalty rate and probability of detection deterring individuals from evading their taxes. Allingham and Sandmo's framework has been the subject of extensive research among taxation scholars, and some of this research has supported the suggestion that variations in the perceived certainty and severity of punishment do shape people's taxpaying behaviour (see Andreoni, Erard and Feinstein 1998, Fischer, Wartick and Mark 1992, Franzoni 2000). For example, evidence of the effects of audit or detection probability has been found using actual taxpayer data (e.g., Witte and Woodbury 1985), in experimental studies (e.g., 
Alm, McClelland and Schulze 1992, Alm, Sanchez and DeJuan 1995), and survey research (e.g., Kinsey and Grasmick 1993, Varma and Doob 1998). Similarly, there is evidence for the positive effects of sanction severity on tax compliance (e.g., Alm et al. 1995, Wenzel 2004). It should be noted, however, that other studies have yielded inconsistent findings (e.g., Dubin, Graetz and Wilde 1987, Dubin and Wilde 1988, Elffers, Weigel and Hessing 1987, Webley and Halstead 1986).

Not only has the deterrence model been used by tax authorities to deter would-be noncompliers from breaking the law (i.e., as a general deterrent), but it has also been used as a specific deterrent to those who have already been detected and caught evading taxes. The deterrence model makes the assumption that by handing out harsh punishment and penalties to rule-breakers this will deter them from re-offending in the future. Evidence to suggest such an approach can work comes from a recent tax study conducted in Australia. Williams (2001) analysed tax return data from 528 taxpayers who had previously been prosecuted for failing to lodge their tax returns with the Australian Taxation Office. His results showed that prosecutions were successful in obtaining subsequent lodgement compliance, but he qualified this by showing that lodgement rates reduced significantly in subsequent years once the initial threat of deterrence had subsided.

Although research supports the basic premise of the deterrence model and its ability to deter people from breaking the law, research also suggests that estimates of the likelihood of being caught and punished have, at best, a minor influence on people's law related behaviour. Some studies suggest that such estimates do not independently influence behaviour when the influence of other factors is considered. Another criticism of the deterrence model is that it does not satisfactorily explain the high levels of voluntary compliance observed in many situations. If people were simply rational actors motivated purely by self-interest, one would expect that compliance with rules and regulations would be significantly lower than what has currently been observed. Third, deterrence systems tend to be costly to maintain. A growing body of research also suggests that deterrence-based enforcement strategies with offenders can sometimes be counterproductive in the long term, and can undermine the relationship between legal authorities and those they regulate (e.g., Ayres and Braithwaite 1992, Blumenthal, Christian and Slemrod 1998, Kagan Scholz 1984, Tyler, Sherman, Strang, Barnes and Woods 2007). In fact, research into reactance has shown that the use of threat and legal coercion, particularly when perceived as illegitimate, can produce the opposite behaviour from that sought; these actions are more likely to result in further non-compliance (Brehm and Brehm 1981, Murphy and Harris 2007), creative compliance (McBarnet 2003), criminal behaviour or overt opposition (Fehr and Rokenbach 2003, Frey 1997, Kagan and Scholz 1984, Unnever, Colvin and Cullen, 2004). Kagan and Scholz (1984) further argue that unreasonable behaviour by regulators during an enforcement experience generates resistance to compliance. They suggest that unreasonableness may involve disrespect for citizens, or arbitrary refusal to take their concerns into account in the enforcement process. They suggest that citizen response to such unreasonableness is likely to be weakened respect for authority and the law.

In the 1980s, therefore, many regulatory scholars began to question the value of deterrence alone in regulating behaviour. Regulatory scholars began to focus their attention on researching compliance rather than deterrence and began to realise the importance of persuasion and 
cooperation as a regulatory tool for gaining compliance. As a result of this work some regulatory agencies began adopting accommodative models of regulation (see Grabosky and Braithwaite 1986). It should be noted that tax authorities have not adopted this approach and have predominantly continued with the deterrence-based models of enforcement (but see the recent approach by the Australian Taxation Office, and New Zealand's Department of Inland Revenue: Job, Stout and Smith, 2007). Regulatory agencies advocating the accommodative model of regulatory enforcement tend to view individuals not as 'rational actors' but as 'social actors' who are ordinarily inclined to comply with the law, partly because of the belief in the rule of law, and partly as a matter of long-term self interest (Kagan and Scholz 1984). Regulatory authorities adopting the accommodative model tend to be more oriented toward seeking results through cooperation rather than by coercion, and prefer to see themselves as service providers rather than as strict law enforcers. These agencies are more likely to give second chances, they give advice about how to comply, and may agree to ignore one violation in return for a correction to another violation (Kagan and Scholz 1984). An important aspect of the accommodative approach is that it aims to establish a collaborative relationship between the regulator and regulatee (Grabosky and Braithwaite 1986, p. 207).

Research in the field of procedural justice has been one area that has shown the value of using an accommodative approach to regulating behaviour. This research has shown that being treated politely, with dignity and respect, being given a say, and having genuine respect shown for one's rights and social status - criteria associated with procedural justice - all enhance feelings of fairness among those being regulated. Tyler (1997) has specifically shown that people value respectful treatment by authorities and view those authorities that treat them with respect as more entitled to be obeyed. A growing number of studies have also demonstrated the positive effects of procedural justice on taxpayer behaviour (see Alm, Jackson and McKee 1993, Feld and Frey 2002, Murphy 2005, Wenzel 2002). In fact, Murphy (in press) has demonstrated that procedural justice can be particularly useful in nurturing compliance with tax laws for offenders who hold questionable norms about taxpaying honesty. Citing findings such as these, Tyler (2006) argues that if regulators are prepared to first engage in dialogue and fair treatment with those they regulate then this will serve to encourage support for the law and should lower the rate of re-offending.

\section{Reintegrative Shaming Theory}

As was noted in the previous section, deterrence-based enforcement strategies, and unreasonableness by regulators during an enforcement event, can sometimes lead to overt resistance to the law and further non-compliance behaviour. The question that arises here is why might deterrence-based enforcement strategies have such an effect? One possible explanation can be found in Braithwaite's theory of reintegrative shaming. In 1989, John Braithwaite published his influential book Crime, Shame and Reintegration. In it, Braithwaite introduced his theory of reintegrative shaming, which synthesises the predictions of several theoretical perspectives of criminal behaviour into a single framework. Its most distinctive contribution is to focus attention on the effect of shaming; with shaming conceived of as encompassing all forms of social disapproval, including punishment and enforcement. The theory's primary argument is that the communication of disapproval is of central importance to understanding the 
effect that criminal justice actions have on the subsequent offending behaviour of individuals. In other words, this theoretical approach provides a framework in which to directly test the effect that deterrence-based enforcement might have on compliance behaviour.

Braithwaite (1989) distinguishes between two forms of disapproval that occur in response to offending: disapproval that is reintegrative in nature and disapproval that is stigmatizing in nature. According to Braithwaite (1989), disapproval that is reintegrative in nature is carried out in a respectful and healing manner. Here, the disapproval of an act is communicated with respect, and special effort is given to avert labelling and to terminate disapproval with rituals of forgiveness or reconciliation. This form of disapproval can be most closely associated with an accommodative style of regulatory enforcement. An accommodative enforcement approach may include communicating with an offender about the circumstances that led to their offending, cooperating with offenders, and working with them in a collaborative effort to ensure their compliance over the long-term. Braithwaite predicts that reintegrative forms of disapproval will result in less re-offending. Braithwaite and Braithwaite (2001) suggest that reintegrative disapproval results in lower offending, at least in part, because it is more likely to promote feelings of shame and remorse by offenders, and encourages offenders to take responsibility for their wrong-doing and to fix the problem in a constructive manner.

Conversely, Braithwaite argues that disapproval that is stigmatic involves communicating disapproval of a person with disrespect, where offenders are labelled with outcasting identities (e.g., thief, tax cheat), and there are no rituals to terminate disapproval. This form of disapproval can be most closely associated with an enforcement approach that adopts deterrence-based tactics. In the taxation enforcement context, offenders tend to be sent enforcement letters written in technical language that they have purposively violated the tax law, and that they should pay culpability penalties to make amends for their wrong-doing. Little attention is given to personal circumstances, and offenders often have little say in the process. Reintegrative shaming theory predicts that this latter style of disapproval results in greater levels of re-offending. It is argued that stigmatic forms of disapproval are less likely to elicit a sense of remorse in an offender because they serve to humiliate an individual. Here, individuals are more likely to externalise blame for what has happened, are more likely to feel alienated from mainstream values, and are more likely to direct anger towards the entity expressing disapproval (i.e., the regulator). Braithwaite and Braithwaite (2001) argue that such feelings of hostility increase the probability of defiance and non-compliance exhibited by the offender in the future.

While Braithwaite's theory has received considerable attention in the context of blue-collar and juvenile crime (see Hay 2001, Tittle, Bratton and Gertz 2003, Tyler et al. 2007, Zhang 1995, Zhang and Zhang 2004), a question raised by some scholars is whether the theory also translates to white-collar crime (Levi and Suddle 1989). Only a small handful of studies have attempted to test the theory in the taxation context. For example, in a study that drew on a random population sample of 2040 cases, Ahmed and Braithwaite (2004) found that taxpayers who indicated they would blame the ATO and displace their shame in response to being detected and punished for hypothetical tax evasion behaviour were more likely to report having evaded their taxes in their most recent tax return. In another study that drew on survey data from 477 Australian university graduates, Ahmed and Braithwaite (2005) found that the significant relationship between feelings of shame and compliance was mediated by participants' feelings 
of being 'dissociated' from the tax system, where dissociation seemed to reflect disregard for the legitimacy of tax law. Finally, Murphy and Harris (2007) analysed survey data from a group of 652 tax offenders. The taxpayers were asked about their enforcement experience with the tax office. Those who perceived their enforcement experience to be stigmatising in nature were in turn more likely to display anger towards the Tax Office, and were less likely to express feelings of remorse for their wrong-doing. These emotional reactions in turn were found to mediate the effect of stigmatisation on subsequent tax compliance behaviour; in other words, those displaying hostility towards their enforcement experience were more likely to report having evaded their taxes two years later.

\section{THE PRESENT STUDY}

The present study builds upon existing research in two ways. First, its main aim is to assess whether a deterrence- or an accommodative-based approach to enforcement is more effective in increasing support for the law and lowering the rate of re-offending. The study will do this by examining the survey responses of 652 tax offenders who have been through a serious enforcement experience with the Australian Taxation Office (ATO). The study specifically seeks to replicate and extend those findings which suggest that stigmatizing versus reintegrative forms of disapproval are relevant to predicting offending in the context of taxation. Second, it seeks to test whether feelings of resentment towards the law and authority mediate the effect of disapproval on offending behaviour. As is evident from the studies discussed in the preceding section, the focus on shame-related emotions has been a significant focus when testing reintegrative shaming theory. In contrast, the present study intends to examine the impact that disapproval has on feelings of resentment and hostility more generally. The impetus for examining feelings of resentment comes from research cited earlier in this article. As was argued by Braithwaite (1989), stigmatic disapproval can increase levels of hostility and resentment among offenders. It was also noted earlier that regulatory encounters that are seen to be unreasonable can generate resistance to compliance and can generate disrespect for authority and the law (Kagan and Scholz 1984, Tyler et al. 2007). Hence, in the context of taxation enforcement, feelings of resentment towards the tax system and towards authority are likely to play an important role. I propose that resentment and disrespect for the law/authority can be measured in two ways: through a) feelings of resentment towards paying tax, and b) feelings of resentment towards the authorities enforcing the law. Of interest is whether these feelings of resentment mediate the effect of disapproval on subsequent compliance behaviour. A number of specific hypotheses can be identified:

H1. Taxpayers who perceived their enforcement experience to be more reintegrative in nature will be less likely to re-offend, whereas taxpayers who felt stigmatized will be more likely to re-offend.

H2. Taxpayers who felt more reintegrated by their enforcement experience will be less likely to experience feeling of resentment toward taxpaying and towardauthority, whereas taxpayers who felt more stigmatized will be more likely to experience feelings of resentment.

H3. Taxpayers who felt more resentment towards taxpaying and towards authority will be more likely to re-offend. 
H4. The relationship between disapproval style (reintegrative vs. stigmatic) and re-offending will be mediated by feelings of resentment toward paying tax and toward authority.

\section{METHOD}

\section{Participants and Procedure}

The data were taken from a survey of Australian taxpayers (Murphy 2004). All had been penalised by the ATO for being involved in aggressive tax avoidance schemes. Throughout the 1990s tens of thousands of Australian taxpayers invested in what they thought were legitimate tax minimisation schemes. Some years later the ATO announced that the schemes were vehicles for illegal tax avoidance, and moved to recover the taxes owing with interest and penalties. The interesting aspect of this case study is that more than $50 \%$ of the taxpayers involved actively resisted the ATO's attempts to recover the tax owing, and refused to pay back their debts. This group of taxpayers was chosen for the purposes of this study because commentators external to the ATO have been critical of the ATO's handling of the schemes situation. Recommendations made by a Parliamentary committee assigned to investigate the issue criticised the heavy handed enforcement tactics used by the ATO (Senate Economics References Committee, 2002). Hence, it is a case study that offers one of the clearest examples of the potential impact that a punitive deterrence-based enforcement strategy may have on subsequent reactions and behaviours. For a more detailed description of this case study readers are directed to Murphy $(2002,2003)$.

In 2002, the names and addresses of 32,493 taxpayers involved in tax schemes were available for selection from the ATO's case files. A survey was sent in January 2002 to a random sample of 6,000 of these taxpayers. The sample was stratified by Australian State/Territory jurisdiction (i.e., $42 \%$ of the sample resided in the state of Western Australia, so 2,549 West Australian taxpayers were sampled for the present study). Non-respondents were followed up over time. Follow-up was accomplished using an identification number attached to each questionnaire, which was in turn linked to the sample name.

In order to protect investors' privacy, the ATO was responsible for all mailings of the survey and reminder letters. Taxpayers who agreed to participate were asked to return their completed questionnaires in a reply-paid envelope directly to the author for analysis. This procedure ensured that the author did not have access to the names or addresses of sampled investors. It also ensured that the ATO did not have access to any individual taxpayers' survey responses. A total of six mailings were made and by the end of July 2002, a total of 2,292 useable surveys had been received. When adjusted for out-of-scope taxpayers who had died or moved address $(\mathrm{N}=677)$, a response rate of $43 \%$ was obtained. Respondents in the final sample were between 24 and 81 years of age $(\underline{M}=46.50, \underline{\mathrm{SD}}=9.30), 82 \%$ were male, their average personal income level for the previous financial year was approximately AUS $\$ 73,000$ (currently about $€ 43,800$ or US $\$ 62,000$ ), and their average family income was approximately AUS $\$ 93,000$ (currently about $€ 55,800$ or US $\$ 79,000$ ). Using the limited amount of demographic data available from the ATO's case files (i.e., state of residence and sex), it was found that the sample of tax scheme investors who completed the survey was representative of the overall scheme investor population. 
At the back of the initial 2002 survey, respondents were asked if they would be willing to participate in a follow-up study in the future. A total of 1,250 respondents indicated that they would be happy to be contacted again and provided the author with their contact details. In August 2004 - two and a half years after their participation in the first survey - the 1,250 respondents were then directly contacted again by the author and asked to fill in a follow-up survey. Non-responders were again followed up, and after three reminder letters were sent a total of 652 respondents returned a useable questionnaire. When taking into account those who had moved address or died since completing the first survey $(\mathrm{N}=146)$, this resulted in a follow-up response rate of $59 \%$. The data reported in this paper comes from responses given to this second follow-up survey. Respondents in the final sample were between 25 and 76 years of age $(\underline{\mathrm{M}}=50.43, \underline{\mathrm{SD}}=9.00), 83 \%$ were male, $46 \%$ had received a University education, and their average personal income was approximately AUS\$79,000 ( $\underline{\mathrm{SD}}=\mathrm{AUS} \$ 59,000$; at the time of writing the average equated to approximately US\$67,000 or $€ 47,400)$.

\section{Measures}

For the purposes of this study, five categories of variables were of interest: perceptions of fair and respectful enforcement (i.e., reintegration), perceptions of stigmatic enforcement (i.e., stigmatization), resentment towards paying tax, resentment towards authority, and self-reported tax non-compliance. Taxpayers' perceptions of reintegrative disapproval were assessed via a six-item scale. The six-item reintegration measure was based on previous research conducted by Tyler (1990, 2006). Taxpayers were asked to reflect on the ATO's treatment of them during the enforcement process (e.g., 'The ATO cares about the position of taxpayers'); those scoring higher on this scale were more likely to see the ATO as having used reintegrative enforcement methods. Stigmatization was assessed via a four-item scale, based on the work of Harris (2001). Here, taxpayers were also asked to express how they felt they were treated by the ATO during the enforcement experience (e.g., 'Did you feel as though you were treated as a criminal?'); those scoring higher on this scale were more likely to see the ATO as having used stigmatic methods during the enforcement process. Resentment towards paying tax and resentment towards authority were each assessed via two-item scales developed by the author (e.g., 'Do you think the schemes situation has left you feeling bitter about paying tax?' and 'Do you think the schemes situation has left you feeling bitter towards the ATO?', respectively). Resentment towards authority reflected feelings toward the regulator itself (the ATO), and toward government more generally; higher scores on each of the two resentment scales imply greater levels of resentment towards paying tax and authority, respectively. Finally, taxpayers were asked a series of five questions - developed by the author - about how they thought their experiences with the ATO had affected their taxpaying behaviour; a higher score on the scale indicates taxpayers were more engaged in non-compliant behaviour (e.g., 'I no longer declare all of my income'). The Appendix lists all of the questions that were used to construct the scales in this study.

\section{Factor Analysis}

A factor analysis using oblique rotation, and specifying five factors, was conducted to test for the dimensionality of the items used to construct each scale (see Table 1). With this sample it 
was found that all individual items loaded clearly onto their respective factors. Hence, Factor 1 comprised six items that measured reintegration, Factor 2 comprised five items that measured tax non-compliance, Factor 3 comprised four items and measured stigmatization, Factor 4 comprised two items and measured taxpayers' resentment towards paying tax, and Factor 5 comprised two items that measured taxpayers' resentment towards authority. It should be noted that the eigenvalues are suggestive that the resentment of taxpaying and resentment of authority scales may have constituted one factor. This was despite the fact that the factor loadings for each individual item did not overlap in the factor loading table (see Table 1). However, given the theoretical interest in distinguishing taxpayers' views of authority from their views of taxpaying, it was decided to keep these factors separate. This needs to be taken into account when interpreting the findings presented below.

Table 1: Factor Analysis Differentiating Categories of Variables.

\begin{tabular}{lllll}
\hline & \multicolumn{4}{c}{ Factor } \\
\cline { 2 - 5 } Item & 1 & 2 & 3 & 4 \\
\hline 1. Reintegration & & & & \\
ATO cares about taxpayers & -.87 & & & \\
ATO concerned about citizen rights & -.82 & & \\
ATO considers citizens concerns & -.80 & & \\
ATO tries to be fair & -.68 & & \\
ATO respects individuals & -.63 & & \\
ATO treats people with dignity/respect & -.61 & &
\end{tabular}

2. Tax non-compliance

Now use tax system in negative way $\quad .85$

Now look for ways to purposefully cheat $\quad .76$

No longer declare all income $\quad .68$

Now look for ways to recoup losses $\quad .51$

Now more defiant toward ATO $\quad .47$

\section{Stigmatization}

Negative judgments about me $\quad .93$

Treated as bad person $\quad .91$

$\begin{array}{lr}\text { Treated as serial offender } & .90\end{array}$

Felt treated as criminal $\quad .59$

4. Resent taxpaying

Left feeling bitter about taxpaying $\quad .77$

Affected my taxpaying $\quad .54$

5. Resent authority

Left feeling bitter towards government $\quad .73$

\begin{tabular}{ll} 
Left feeling bitter towards ATO & .65 \\
\hline
\end{tabular}

\begin{tabular}{lccccc}
\hline Eigenvalues & 6.66 & 2.96 & 1.95 & 1.18 & .74 \\
Explained variance $(\%)$ & 35 & 16 & 10 & 6 & 4
\end{tabular}

Note: Principal Axis Factoring analysis, oblique rotation. Only factor loadings $>0.30$ are displayed. Questions have been shortened in Table 1 due to space constraints. See Appendix for the full wording of questions. 


\section{RESULTS}

As noted in the Present Study section, this study is interested in assessing the relationship between disapproval, feelings of resentment, and recidivism. In other words, it is interested in addressing whether different forms of disapproval (reintegrative vs stigmatic punishment) are related to feelings of resentment, and whether these feelings of resentment are related to re-offending behaviour.

\section{Bi-Variate Correlations and Mean Scores}

Table 2 presents the bi-variate correlations between all scales measured in the present study, as well as the mean and standard deviation scores for each scale. The first thing to note about the bi-variate correlations is that there is a significant negative correlation between the reintegration measure and the tax evasion measure, and a significant positive correlation between the stigmatization measure and the tax evasion measure. These two results are significant theoretically because they support Braithwaite's (1989) assertion that reintegrative and stigmatic forms of disapproval do have an effect on subsequent compliance behaviour. The first correlation suggests that taxpayers who felt the ATO treated them in an accommodative and reintegrative fashion during their enforcement experience were less likely to report having evaded their taxes in subsequent years. The second correlation suggests that taxpayers who felt stigmatized by their enforcement experience were more likely to re-offend in the years following their experience.

Other noteworthy relationships are that both reintegration and stigmatization were associated with feelings of resentment. Those taxpayers who were more likely to feel their scheme-related enforcement experience with the ATO had been reintegrative in nature were significantly less likely to feel resentment towards taxpaying or towards authority. In contrast, those who were more likely to feel their enforcement experience had been stigmatizing in nature were significantly more likely to feel resentment towards paying tax and towards authority. The feelings of resentment in turn were both positively associated with self-reported tax evasion behaviour, suggesting that non-compliance is more likely to occur when people do not support the law or authority. These associations will be discussed in more detail in the following section.

Table 2: Means and Standard Deviations for Each Scale, and Bi-Variate Correlations

Among All Scales in the Study. Figures in Parentheses are

Cronbach Alpha Reliabillity Coefficients.

\begin{tabular}{lccccccc}
\hline Variables & Mean & SD & 1 & 2 & 3 & 4 & 5 \\
\hline 1. Reintegration & 2.18 & 0.78 & $(.90)$ & & & & \\
2. Stigmatization & 3.70 & 1.00 & $-.44^{* * *}$ & $(.90)$ & & & \\
3. Resent taxpaying & 2.65 & 1.06 & $-.33^{* * *}$ & $.23^{* * *}$ & $(.67)$ & & \\
4. Resent authority & 3.64 & 1.09 & $-.60^{* * *}$ & $.40^{* * *}$ & $.50^{* * *}$ & $(.79)$ & \\
5. Tax non-compliance & 1.90 & 0.72 & $-.23^{* * *}$ & $.09^{*}$ & $.45^{* * *}$ & $.30^{* * *}$ & $(.79)$ \\
\hline
\end{tabular}

Notes: $* \mathrm{p}<0.05, * * \mathrm{p}<0.01,{ }^{* * *} \mathrm{p}<0.001$; all scales measured on a 1 to 5 scale. 
Also of particular note from Table 2 are the mean scores for both the reintegration and stigmatization scales. Of those surveyed, on average, more taxpayers tended to view their enforcement experience to be stigmatic in nature than reintegrative. This finding also confirms the earlier claim that this case study represents a useful case in which to examine the possible negative effects deterrence-based enforcement tactics can have on long-term compliance behaviour.

\section{Regression Analyses and Mediation}

According to Baron and Kenny (1986), perfect mediation exists when four conditions are met. First, the independent variable (i.e., reintegration or stigmatic disapproval) must be related to the mediating variable (i.e., resentment variables). Second, the independent variable must be related to the dependent variable (i.e., non-compliance). Third, there must be a relationship between the mediator (i.e., feelings of resentment) and the dependent variable (i.e., noncompliance). Fourth, the previously significant relationship between the independent variable (i.e., reintegration or stigmatization) and the dependent variable (i.e., non-compliance) is no longer significant after controlling for the mediator (i.e., feelings of resentment). In other words, if it is the case that feelings of resentment truly mediate the relationship between perceptions of reintegrative or stigmatic disapproval and compliance behaviour, then we would expect to see the relationship between the disapproval and compliance behaviour scales to disappear once people's feelings of resentment are taken into account. If on the other hand, perceptions of reintegrative or stigmatic disapproval are more important in predicting compliance behaviour, and feelings of resentment play little or no role in the disapproval-compliance relationship, then entry of feelings of resentment into the model should have no effect on the relationship between disapproval and compliance.

Table 3: Regression Analyses Showing How (a) Reintegration and (b) Stigmatization Predict Resentment Toward Taxpaying

\begin{tabular}{|c|c|c|c|c|c|c|}
\hline \multirow[b]{2}{*}{ Predictor } & \multicolumn{3}{|c|}{ (a) } & \multicolumn{3}{|c|}{ (b) } \\
\hline & B & $\mathrm{SE}_{\mathrm{B}}$ & $\beta$ & B & $\mathrm{SE}_{\mathrm{B}}$ & $\beta$ \\
\hline Reintegration & -.44 & .05 & $-.33^{* * *}$ & - & - & - \\
\hline Stigmatization & - & - & - & .25 & .04 & $.23^{* * *}$ \\
\hline Constant & 3.62 & .12 & - & 1.75 & .16 & - \\
\hline $\mathrm{R}^{2}$ & & .11 & & & .05 & \\
\hline df & & 1,645 & & & 1,640 & \\
\hline
\end{tabular}

So, do feelings of resentment mediate the effect of reintegrative and stigmatic forms of disapproval on subsequent compliance behaviour? To test this question a series of hierarchical regression analyses were performed. The first two regression analyses used 'reintegration' and 'stigmatization' to predict resentment toward taxpaying, respectively (see Table 3). As can be seen in Part (a) of Table 3, 'reintegration' significantly predicted feelings of resentment towards paying tax. In other words, those who were more likely to feel their enforcement experience with the ATO had been handled in a reintegrative fashion were less likely to feel resentment 
towards paying tax at the time of completing the survey. Similarly, Part (b) of Table 3 shows that 'stigmatization' also significantly predicted feelings of resentment towards paying tax; those who believed their enforcement experience had been more stigmatic in nature were significantly more likely to feel resentment towards paying tax in the years following their enforcement experience.

The second two regression analyses used 'reintegration' and 'stigmatization' to predict resentment toward authority, respectively (see Table 4).

Part (a) of Table 4 shows that 'reintegration' significantly predicts resentment toward authority in a negative direction, and Part (b) of Table 4 shows that 'stigmatization' significantly predicts resentment toward authority in a positive direction. These findings suggest that those who felt stigmatized by their enforcement experience were more likely to feel resentment toward authority, while those who were more likely to feel their enforcement experience had been reintegrative in nature were less likely to feel resentment toward authority. The findings presented in both Table 3 and 4 confirm the bi-variate correlations presented in Table 2, and they provide confirmatory evidence to support Hypothesis 2. The findings also meet Baron and Kenny's (1986) first criterion of mediation that the independent variable (i.e., reintegration or stigmatic disapproval) must be related to the mediating variables (i.e., resentment variables).

Table 4: Regression Analyses Showing How (a) Reintegration and (b) Stigmatization Predict Resentment Toward Authority

\begin{tabular}{|c|c|c|c|c|c|c|}
\hline \multirow[b]{2}{*}{ Predictor } & \multicolumn{3}{|c|}{ (a) } & \multicolumn{3}{|c|}{ (b) } \\
\hline & B & $\mathrm{SE}_{\mathrm{B}}$ & $\beta$ & B & $\mathrm{SE}_{\mathrm{B}}$ & $\beta$ \\
\hline Reintegration & -.85 & .04 & $-.60^{* * * *}$ & - & - & - \\
\hline Stigmatization & - & - & - & .44 & .04 & $.40^{* * *}$ \\
\hline Constant & 5.48 & .10 & - & 2.02 & .15 & - \\
\hline $\mathrm{R}^{2}$ & & & .37 & .16 & & \\
\hline df & & 1,645 & & & 1,640 & \\
\hline
\end{tabular}

Tables 5 and 6 present the results that demonstrate that feelings of resentment mediate the effect of reintegration (Table 5) and stigmatisation (Table 6) on non-compliance behaviour. When examining respondents' tax non-compliance behaviour, the findings reported in Step 1 of Table 5 show that 'reintegration' significantly predicted 'tax non-compliance behaviour'. Those taxpayers who were more likely to feel their treatment by the ATO in 2002 was reintegrative in nature were less likely to report having evaded their taxes two years later. Hence, support was found for Hypothesis 1. Also of interest is the finding that 'resentment toward taxpaying' predicted 'non-compliance' when entered into the model at Step 2. Those taxpayers who resented paying tax were more likely to report evading their taxes. Surprisingly, when both 'reintegration' and 'resentment toward taxpaying' were included in the model, 'resentment toward authority' did not predict non-compliance behaviour.

Of more importance, however, is the finding that 'resentment toward taxpaying' appeared to mediate the effect of reintegration on tax evasion behaviour. When the resentment variables were entered into the model at Step 2, 'reintegration' no longer remained a significant predictor 
of tax evasion behaviour. This significant mediation effect was confirmed via a Sobel test, which revealed that taxpaying resentment did significantly mediate the effect of reintegration on tax non-compliance behaviour, $\mathrm{z}=-6.57, \mathrm{p}<0.001$. Hence, resentment of taxpaying, but not resentment of authority, mediated taxpayers' perceptions of reintegration on their subsequent compliance behaviour. These particular findings lend partial support to Hypothesis 4.

Table 5: Regression Analysis Exploring the Mediational Role of Resentment in the Reintegration and Tax Non-Compliance Relationship

\begin{tabular}{|c|c|c|c|c|c|c|}
\hline \multirow[b]{2}{*}{ Predictor } & \multicolumn{3}{|c|}{ Step 1} & \multicolumn{3}{|c|}{ Step2 } \\
\hline & $\mathrm{B}$ & $\mathrm{SE}_{\mathrm{B}}$ & $\beta$ & $\mathrm{B}$ & $\mathrm{SE}_{\mathrm{B}}$ & $\beta$ \\
\hline Reintegration & -.21 & .04 & $-.23^{* * *}$ & -.06 & .04 & -.06 \\
\hline Resent taxpaying & - & - & - & .27 & .03 & $.40^{* * * *}$ \\
\hline Resent authority & & & & .04 & .03 & .06 \\
\hline Constant & 2.36 & .08 & - & 1.17 & .18 & - \\
\hline $\mathrm{R}^{2}$ & & .05 & & & .21 & \\
\hline $\mathrm{R}^{2}$ change & & .05 & & & .16 & \\
\hline F change & & $35.66^{* * *}$ & & & $65.14^{* * *}$ & \\
\hline df & & 1,644 & & & 2,642 & \\
\hline
\end{tabular}

Note: The dependent measure is tax non-compliance.

Table 6: Regression Analysis Exploring the Mediational Role of Resentment in the Stigmatization and Tax Non-Compliance Relationship

\begin{tabular}{|c|c|c|c|c|c|c|}
\hline \multirow[b]{2}{*}{ Predictor } & \multicolumn{3}{|c|}{ Step 1} & \multicolumn{3}{|c|}{ Step2 } \\
\hline & B & $\mathrm{SE}_{\mathrm{B}}$ & $\beta$ & $\mathrm{B}$ & $\mathrm{SE}_{\mathrm{B}}$ & $\beta$ \\
\hline Stigmatization & .07 & .03 & $.09^{*}$ & -.03 & .03 & -.05 \\
\hline Resent taxpaying & - & - & - & .27 & .03 & $.41^{* * * *}$ \\
\hline Resent authority & & & & .08 & .03 & $.12^{* *}$ \\
\hline Constant & 1.65 & .11 & - & 1.02 & .11 & - \\
\hline $\mathrm{R}^{2}$ & & .01 & & & .21 & \\
\hline $\mathrm{R}^{2}$ change & & .01 & & & .20 & \\
\hline F change & & $5.57^{*}$ & & & $83.44^{* * *}$ & \\
\hline df & & 1,640 & & & 2,638 & \\
\hline
\end{tabular}

Note: The dependent measure is tax non-compliance.

The results of the stigmatization findings show a somewhat different pattern of results (see Table 0 ). Here both resentment toward taxpaying and resentment toward authority mediated taxpayers' perceptions of stigmatization on their compliance behaviour. Step 1 of Table 6 first shows that perceptions of stigmatization predicted non-compliance; those taxpayers who perceived their enforcement experience to be more stigmatic in nature were more likely to report having evaded their taxes at the time of completing the survey. However, once resentment toward taxpaying and resentment toward authority were entered into the model at Step 2, stigmatization no longer remained a significant predictor of compliance behaviour. Sobel tests confirmed these mediation effects $(z=5.13, p<0.001$ and $z=2.59$, $\mathrm{p}<0.01$ for both taxpaying resentment and authority resentment, respectively). At the same 
time, both resentment toward taxpaying and resentment toward authority predicted noncompliance behaviour; those more likely to resent paying tax and those more likely to resent authority were more likely to have evaded their taxes. The outcome of this analysis supports the predictions made in Hypotheses 1, 3 and 4.

\section{Methodological Limitations}

Before proceeding to discuss the findings, the methodological limitations of the present study should first be highlighted. First, it is important to note that a self-report measure of tax non-compliance was used as the measure of compliance in the present study. A method that relies on the honesty of the surveyed participants to disclose dishonest behaviour is obviously vulnerable to a challenge to its validity. However, participants were made aware their responses would be kept confidential, and a strong tradition of research in psychology and criminology supports the validity of using self-report data in such circumstances (Maxfield and Babbie 2008, Thornberry and Krohn 2000). Second, while the case study presented provided a remarkably useful dataset for examining the perceptions of a large number of tax offenders, it is not without its limitations. Given the cross-sectional nature of the survey data, it is impossible to make definitive conclusions about the causal direction of any relationships that are found. Accordingly, the results should be interpreted in this light. Third, and perhaps more problematic, is the finding that both stigmatization and reintegration explain only a small amount of the variation in compliance behaviour (see $\mathrm{R}^{2}$ values in Step 1 of Tables 5 and 6 ). Prior research has found that fair treatment effects have their greatest effect on compliance behaviour prior to or soon after a decision has been made by an authority (see Ambrose and Cropanzano 2003). Hence, a study that tests compliance some time after the initial enforcement experience - as in the present study - may fail to find a strong effect. More research will need to be conducted in this area to ascertain whether the findings can be replicated.

\section{DISCUSSION}

Taxation researchers have found that regulatory enforcement strategies that rely on deterrence principles can be used to deter people from breaking the law. However, a growing body of research has revealed that deterrence-based enforcement strategies used with offenders can sometimes generate future resistance to compliance and, under extreme conditions, can encourage game-playing and blatant disrespect for authority and the law (e.g., Ayres and Braithwaite 1992, Braithwaite 2003, Kagan and Scholz, 1984, McBarnet 2003, Tyler 2006). The aim of the present study, therefore, was to test empirically whether deterrence-based enforcement strategies might generate feelings of resistance and might be less effective in nurturing future compliance among tax offenders, than strategies based on persuasion and cooperation. The theoretical framework used to test this was Braithwaite's theory of reintegrative shaming. While others in the taxation field have examined compliance behaviour using this theoretical framework (see Ahmed and Braithwaite 2004, 2005, Murphy and Harris 2007), they have primarily concentrated on the role that shame-related emotions play in the disapproval/compliance relationship. Given regulatory research more broadly has suggested 
that deterrence-based enforcement tactics can generate resistance to compliance and disrespect for law, it seemed prudent to examine the role that feelings of resentment toward paying tax and towards authority might play in this relationship. Specifically, the study explored the relationship between tax offenders' perceptions of their enforcement experience (whether they perceived it to be reintegrative or stigmatizing in nature), the feelings of resentment the enforcement experience elicited, and the effect that these variables had on subsequent compliance behaviour. Of particular interest was the hypothesis that feelings of resentment would mediate the relationship between people's perceptions of stigmatization/reintegration and their subsequent compliance behaviour.

The study yielded a couple of interesting and important findings. One important finding in this study is that those who perceived the ATO's treatment of them as more stigmatic in nature were more likely to report that they had evaded their taxes in the years following their enforcement experience. In contrast, those who perceived the ATO's treatment of them as more reintegrative were less likely to report that they had subsequently evaded their taxes. As discussed at the end of the results section causality cannot be determined from this data because it is cross sectional rather than longitudinal. Nevertheless, these results provide some support for the central prediction of reintegrative shaming theory; that reintegration of offenders leads to lower re-offending, while its opposite, stigmatisation, leads to greater re-offending. This finding also adds to the growing number of studies that suggest reintegrative shaming theory is relevant to explaining white-collar crime (Benson 1990, Braithwaite and Drahos 2002, Makkai and Braithwaite 1994, Murphy and Harris 2007).

The second focus of this study was to explore the mediating role that feelings of resentment play in the disapproval-compliance relationship. It was found that resentment did play an important role in the relationship between perceptions of disapproval and subsequent compliance behaviour. First, taxpayers who felt the ATO had stigmatized them were more likely to feel both resentment towards paying tax and resentment towards authority. In contrast, those taxpayers who felt their enforcement encounter had been handled in a reintegrative manner were less likely to feel resentment towards taxpaying or towards authority. Second, it is also important to note that the feelings of resentment taxpayers felt towards paying tax and towards authority also predicted non-compliance behaviour; those who were more likely to resent paying tax or who were more likely to resent authority were in turn more likely to report having evaded their taxes. The most interesting finding, however, was that feelings of resentment mediated the effect of disapproval on compliance behaviour. Resentment towards paying tax mediated the effect of both stigmatization and reintegration on subsequent compliance behaviour, and feelings of resentment towards authority were found to mediate the effect of stigmatization on compliance behaviour. Hence, general support was found for the hypothesis that resentment can mediate the effect of different forms of disapproval on compliance behaviour.

Taken together, these findings have important implications for the study of white-collar crime. The results suggest that feelings of resentment are pertinent to individuals who are accused and punished for tax evasion, and they may play a significant role in determining how they comply with the law in the future. This finding also supports the assertions made by regulatory scholars from other fields who suggest that unreasonable behaviour from regulators during an enforcement encounter can generate resistance to compliance and disrespect for authority. 
While tax evasion may be distinct from other forms of white-collar crime, the results of this study support placing greater emphasis on understanding the social and emotional impact of regulation on white-collar offenders (see Fisse and Braithwaite 1983, Ayres and Braithwaite 1992, Benson 1990, Elis and Simpson 1995).

\section{Implications for Regulatory Enforcement Models}

While the present study has been able to lend general support to the theoretical framework underlying reintegrative shaming theory in the white-collar crime context, the findings of the present study also have wider implications for the area of regulatory enforcement in the taxation context. The aim of regulatory enforcement is to gain future compliance from offenders. At the same time, however, enforcement practices should not result in the alienation of those they come into contact with. In an area such as taxation, like in many other regulatory contexts, the behaviour being regulated is continuous and fundamental to the long-term health of the community. In such a regulatory context, the goal should therefore be to secure long-term voluntary compliance. This paper started out by contrasting the deterrence versus accommodative models of regulation. The pros and cons of each style were discussed, and an argument was put forth as to why deterrence-based strategies might be counterproductive in meeting regulatory goals in the long term.

The circumstances surrounding the case study used in this article, and the empirical survey findings reported here are pertinent to this argument. What they demonstrate is that deterrencebased enforcement tactics can serve to stigmatize offenders, which in turn can leave them feeling resentful towards paying tax and towards the authority enforcing the rules. Despite these findings, however, it is not the intention of this paper to suggest that tax offenders should not be punished for their crimes because of the possibility such punishment may lead to further re-offending. The question here is not about whether or not a tax authority should punish tax offenders, but instead about how a tax authority should punish these taxpayers in order to secure their long-term voluntary compliance. The findings of the present study suggest that in order to prevent possible re-offending after an enforcement experience, regulators should aim to adopt enforcement procedures that emphasise reintegration and the fair treatment of offenders.

If reintegrative enforcement is the key to promoting long-term compliance with the law, one might wonder just how it might be applied practically to a field such as taxation regulation. It is not hard to recognise the challenge that faces a regulator responsible for managing the behaviour of millions of taxpayers, and hence, the reasons for why a deterrence-based approach may be seen to be the most practical solution to a compliance problem. In fact, in their analysis of the enforcement styles of 96 Australian regulators, Grabosky and Braithwaite (1986) observed that those regulators who regulate a relatively small number of companies/individuals tended to resort to less formal means of achieving compliance than those who regulate a relatively large number of companies/individuals. They argued that this was due to the fact that it was easier to establish more cooperative and collaborative relationships with smaller numbers of regulatees.

Given the large volume of taxpayers, it is necessary in such a context to establish an automated process which can engage with the masses. Here, reintegrative forms of enforcement 
cannot be practiced routinely on a one-to-one basis with offenders as it is in other fields (e.g., Morris and Maxwell 2001, Sherman, Strang and Wood 2000). This does not mean, however, that it is not possible to implement a reintegrative enforcement approach in such an area. In a recent paper, Murphy and Harris (2007) suggest that tax authorities can move in the direction of reintegrating offenders by changing their communication strategies with taxpayers. Communication that aims to respect individuals by respecting their rights to privacy and confidentiality, providing them with explanations for enforcement decisions, and providing opportunities to contest decisions and reach agreements, are all ways in which improvements can be made in the direction of recognising the importance of reintegration in an enforcement context (see also Braithwaite 2006).

Evidence to suggest that such an approach can be developed relatively easily in an automated environment comes from a recent Australian taxation study conducted by Wenzel. Wenzel(2006) studied the effectiveness of different reminder letters that reminded small business taxpayers about their requirements to lodge their quarterly business activity statements with the ATO. Taxpayers in his study were all non-compliant taxpayers as they had all failed to lodge their business activity statements to the ATO by the required date. Working with the ATO, Wenzel tested three different letters on subsequent lodgement compliance. The first was the ATO's standard reminder letter which made penalties and punishment salient. The other two letters focussed on principles of procedural fairness (principles that share many commonalities with reintegrative principles). The first of these procedural justice letters emphasised consideration and respect for taxpayers (i.e., interpersonal fairness), while at the same time communicating to the taxpayers that they had not fulfilled their taxation obligations under the tax code, which is broadly consistent with the approach proposed by reintegrative shaming theory. The second letter provided taxpayers with information about their obligations and provided justifications for the ATO's decision to pursue them further (i.e., informational justice). Each of the three letters was sent to a random sample of taxpayers $(\mathrm{N}=2052)$. It was found that both the informational and interpersonal letter yielded greater lodgement compliance from individuals compared to the standard ATO letter. Importantly, it was also found that fewer complaints were made to the ATO from taxpayers who received the informational and interpersonal letters (Wenzel 2002). Hence, these findings demonstrate that changing existing deterrence-based communication strategies can achieve a simple, inexpensive, yet effective way of changing tax offenders' behaviour for the positive. Care must be taken, however, that new forms of communication with offenders do not communicate tolerance for non-compliance, as such an approach has also been found to increase subsequent non-compliance (see Makkai and Braithwaite 1994). The trick to successful regulation is to create a synergy between regulating in a fair and reintegrative manner with an approach that still communicates firmness and disapproval of the wrongful act.

\section{CONCLUSION}

While the findings of the present study have been able to extend prior research by showing that feelings of resentment can mediate the relationship between disapproval and compliance behaviour in the taxation context, the findings also have wider implications for how regulators and authority figures can more effectively nurture compliance among those they regulate. 
Having a better understanding of why and when people are motivated to comply with decisions and rules can provide authorities with more effective strategies aimed at managing those they regulate. As noted by Lange (2002), regulating is not just about formal law, but also involves the generation, expression, and management of feelings and emotions. The findings of the present study specifically point to the importance of considering the potential impact decisions and enforcement tactics have on people's subsequent emotional reactions. The findings of the present study show that feelings of resentment play an important role in predicting when a person will or will not comply with their obligations. In particular, enforcement strategies that elicit feelings of resentment towards compliance and towards authority appear to lead to subsequent non-compliance among those affected. In contrast, reintegrative tactics that serve to reduce feelings of resentment appear to foster compliance with rules. It is suggested that learning to better manage such emotions will leave regulators and authorities with a better ability to shape compliance in the future. Hence, the challenge for authorities will be to gain support for their decisions and rules through using strategies that are seen to be reintegrative and fair.

\section{REFERENCES}

Ahmed, E. and V. Braithwaite (2004). When tax collectors become collectors for child support and student loans: jeopardizing or protecting the revenue base?, Kyklos. 3: 303-326.

Ahmed, E. and V. Braithwaite (2005). A need for emotionally intelligent policy: linking tax evasion with higher education funding, Legal and Criminological Psychology. 10: 291-308.

Allingham, M. and A. Sandmo (1972). Income tax evasion: a theoretical analysis, Journal of Public Economics. 1: 323-338.

Alm, J., B. Jackson, and M. McKee (1993). Fiscal exchange, collective decision institutions, and tax compliance, Journal of Economic Behaviour and Organization. 22: 285-303.

Alm, J., G. McClelland and W. Schulze (1992). Why do people pay taxes?, Journal of Public Economics. 48: 21-38.

Alm, J., I. Sanchez and A. DeJuan (1995). Economic and noneconomic factors in tax compliance, Kyklos. 48: 3-18.

Ambrose, M. and R. Cropanzano (2003). A longitudinal analysis of organizational fairness: an examination of reactions to tenure and promotion decisions, Journal of Applied Psychology. 88: E66-275.

Andreoni, J., B. Erard, and J. Feinstein (1998). Tax compliance, Journal of Economic Literature. 36: 818-860.

Ayres, I. and J. Braithwaite (1992). Responsive Regulation: Transcending the deregulation debate. New York: Oxford University Press.

Baron, R.M. and D. A. Kenny (1986). The moderator-mediator variable distinction in social psychological research: conceptual, strategic, and statistical considerations, Journal of Personality and Social Psychology. 51: 1173-1182.

Beccaria, C. ([1797] 1986). On Crimes and Punishment (translated from Italian). Indianapolis: Hackett Publishers.

Becker, G.S. (1968). Crime and punishment: an econometric approach, Journal of Political Economy. 76: $169-217$.

Benson, M. (1990). Emotions and adjudication: status degradation among white-collar criminals, Justice Quarterly. 7: 515-528

Bentham, J. ([1788] 1983). Principles of Penal Law, reprinted in: J. H. Burton (ed), The Works of Jeremy Bentham. Philadelphia: Lea and Blanchard. 
Blumenthal, M., C. Christian, and J. Slemrod (1998). The determinants of income tax compliance: evidence from a controlled experiment in Minnesota, National Bureau Of Economic Research Working Paper No. 6575, Massachusetts, Usa.

Braithwaite, J. (1989). Crime, Shame and Reintegration. Cambridge: Cambridge University Press.

Braithwaite, J., and V. Braithwaite (2001). Shame, shame management and regulation, in E. Ahmed, N. Harris, J. Braithwaite, and V. Braithwaite, Shame Management Through Reintegration. Cambridge: Cambridge University Press.

Braithwaite, J. and P. Drahos (2002). Zero tolerance, naming and shaming: is there a case for it with crimes of the powerful?, The Australian and New Zealand Journal of Criminology. 35: 269-288.

Braithwaite, V. (2003). Dancing with Tax Authorities: Motivational Postures and Non-compliant Actions. In V. Braithwaite (ed.), Taxing Democracy: Understanding Tax Avoidance and Evasion. Aldershot: Ashgate Publishing.

Braithwaite, V. (2006). Is reintegrative shaming relevant to tax evasion and avoidance? Paper presented at the Managing and Maintaining Compliance Conference, Leiden, Netherlands, April 9-11, 2006.

Brehm, S. S. and J. W. Brehm (1981). Psychological Reactance: A Theory of Freedom and Control. New York: Academic Press.

Dubin, J., M. Graetz, and L. Wilde (1987). Are we a nation of tax cheaters? New econometric evidence on tax compliance, The American Economic Review. 77: 240-245.

Dubin, J. and L. Wilde (1988). An Empirical Analysis of Federal Income Tax Auditing and Compliance, National Tax Journal. 16: 61-74.

Elffers, H., R.H. Weigel, and D. J. Hessing (1987). The consequences of different strategies for measuring tax evasion behaviour, Journal of Economic Psychology. 8: 311-337.

Elis, L. and S. Simpson (1995). Informal sanction threats and corporate crime: Additive versus multiplicative models, Journal of Research in Crime and Delinquency. 32: 399-424.

Fehr, E. and B. Rockenbach (2003). Detrimental effects of sanctions on human altruism, Nature. 422: 137-140.

Feld, L. and B. Frey (2002). Trust breeds trust: How taxpayers are treated, Economics of Governance. 3: 87-99.

Fischer, C., M. Wartick, and M. Mark (1992). Detection probability and taxpayer compliance: A review of the literature, Journal of Accounting Literature. 11: 1-46.

Fisse, B. and J. Braithwaite (1983). The impact of publicity on corporate offenders. Albany: University of New York Press.

Franzoni, L. (2000). Tax evasion and tax compliance, in: B. Bouckaert and G. DeGeest (eds.), Encyclopaedia of Law and Economics, Vol. 4. Cheltenham, UK: Elgar.

Frey, B. (1997). A constitution for knaves crowds out civic virtue, The Economic Journal. 107: 10431053.

Gibbs, J. P. (1968). Crime, punishment and deterrence, Southwestern Social Science Quarterly. 48: 515-530.

Grabosky, P. and J. Braithwaite (1986). OfManners Gentle: Enforcement strategies of Australian Business Regulatory Agencies. Melbourne: Oxford University Press.

Harris, N. (2001). Testing the dimensionality of shaming, in: E. Ahmed, N. Harris, J. Braithwaite, and V. Braithwaite (eds.), Shame Management Through Reintegration. Cambridge: Cambridge University Press.

Hay, C. (2001). An exploratory test of Braithwaite's reintegrative shaming theory, Journal of Research in Crime and Delinquency. 38: 132-153.

Jensen, G.F. (1969). Crime doesn't pay: correlates of a shared misunderstanding, Social Problems. 17: 189-201.

Job, J., A. Stout and R. Smith (2007). Culture change in three taxation administrations: from commandand-control to responsive regulation, law and policy. 29: 84-101.

Kagan, r. A. And j. T. Scholz (1984). The criminology of the corporation and regulatory enforcement strategies, in: K. Hawkins and J. M. Thomas (eds.), Enforcing regulation. Boston: Kluwer-Nijhoff Publishing. 
Kinsey, K. and H. Grasmick (1993). Did the tax reform act of 1986 improve compliance? Three studies of pre- and post-TRA compliance attitudes, Law and Policy. 15: 239-325.

Lange, B. (2002). The emotional dimension of legal regulation, Journal of Law and Society. 29: 197225.

Levi, M. M. Suddle (1989). White-collar crime, shamelessness, and disintegration: The control of tax evasion in Pakistan, Journal of Law and Society. 16: 489-505.

Makkai, T., and J. Braithwaite (1994). Reintegrative shaming and compliance with regulatory standards, Criminology. 32: 361-385.

Maxfield, M. G., and E. Babbie (2008). Research Methods for Criminal Justice and Criminology (5th ed). Belmont, CA: Thomson Wadsworth.

McBarnet, D. (2003). When compliance is not the solution but the problem: from changes in law to changes in attitude, in: V. Braithwaite (ed.), Taxing Democracy: Understanding Tax Avoidance and Evasion. Aldershot: Ashgate.

Morris, A., and G. M. Maxwell (2001). Restorative justice for juveniles: Conferencing, Mediation and Circles. Oxford: Hart.

Murphy, K. (2002). Procedural justice and the Australian Taxation Office: A study of tax scheme investors, Centre for Tax System Integrity Working Paper No. 35, Canberra: The Australian National University.

Murphy, K. (2003). Procedural justice and tax compliance, Australian Journal of Social Issues. 38 : 379-407.

Murphy, K. (2004). The Australian Tax System Survey of Tax Scheme Investors: A follow-up survey, Canberra: The Centre for Tax System Integrity, Research School of Social Sciences, Australian National University.

Murphy, K. (2005). Regulating more effectively: The relationship between procedural justice, legitimacy and tax non-compliance, Journal of Law and Society. 32: 562-589.

Murphy, K. (in press). Procedural justice and the regulation of tax compliance behaviour: the moderating role of personal norms, in: J. Alm, J. Martinez-Vazquez and B. Torgler (eds.), Tax Compliance and Tax Evasion. London: Routledge.

Murphy, K. and N. Harris (2007). Shaming, shame and recidivism: A test of reintegrative shaming theory in the white-collar crime context, British Journal of Criminology. 47: 900-917.

Senate Economics References Committee (2002). Inquiry into Mass Marketed Tax Effective Schemes and Investor Protection: Final Report. Canberra: Parliament of Australia.

Sherman, L., H. Strang and J. Wood (2000). Recidivism patterns in the Canberra reintegrative shaming experiments. Canberra: Research School of Social Sciences, The Australian National University.

Thornberry, T. P. and M. D. Krohn (2000). The self-report method for measuring delinquency and crime, in: Duffee (ed.), Measurement and Analysis of Crime and Justice: Criminal Justice 2000, Vol. 4. Washington DC: US Department of Justice.

Tittle, C.R. (1969). Crime rates and legal sanctions. Social Problems. 16: 409-423.

Tittle, C.R., J. Bratton, and M. G. Gertz (2003). A test of a micro-level application of shaming theory. Social Problems. 50: 592-617.

Tyler, T. R. (1990). Why people obey the law. New Haven, CT: Yale University.

Tyler, T. R. (1997). The psychology of legitimacy: A relational perspective on voluntary deference to authorities, Personality and Social Psychology Review. 1: 323-345.

Tyler, T. R. (2006). Why people obey the law. Princeton: Princeton University Press.

Tyler, T. R., L. Sherman, H. Strang, G. Barnes, and D. Woods (2007). Reintegrative shaming, procedural justice, and recidivism: The engagement of offenders' psychological mechanisms in the Canberra RISE Drinking-and-Driving Experiment, Law and Society Review. 41: 553-586.

Unnever, J., M. Colvin, and F. Cullen (2004). Crime and coercion: A test of core theoretical propositions, Journal of Research in Crime and Delinquency. 41: 219-243.

Varma, K. and A. Doob (1998). Deterring economic crimes: The case of tax evasion, Canadian Journal of Criminology. 40: 165-184. 
Webley, P. and S. Halstead (1986). Tax evasion on the micro: Significant simulations or expedient experiments?, The Journal of Interdisciplinary Economics. 1: 87-100.

Wenzel, M. (2002). Principles of procedural fairness in reminder letters: A field experiment. Centre for Tax System Integrity Working Paper No. 42. Canberra: The Australian National University.

Wenzel, M. (2004). The social side of sanctions: Personal and social norms as moderators of deterrence, Law and Human Behavior. 28: 547-567.

Wenzel, M. (2006). A letter from the tax office: compliance effects of informational and interpersonal justice, Social Justice Research. 19: 345-364.

Williams, R. (2001). Prosecuting non-lodgers: To persuade or punish? Centre for Tax System Integrity Working Paper No. 12, Canberra: The Australian National University.

Witte, A. D. and D. F. Woodbury (1985). The effect of tax laws and tax administration on tax compliance: The case of the US individual income tax, National Tax Journal. 38: 1-15.

Zhang, S. (1995). Measuring shaming in an ethnic context, British Journal of Criminology. 35: 248262.

Zhang, L., S. Zhang (2004). Reintegrative shaming and predatory delinquency, Journal of Research in Crime and Delinquency. 41: 433-453. 


\section{APPENDIX}

Contained in the Appendix is a complete list of the measures used in the analyses of this paper. It also details the original scale formats, reliability coefficients of each scale, the mean score and standard deviation obtained on each scale.

\section{Reintegration.}

Items measured on a $1=$ strongly disagree to $5=$ strongly agree scale (Cronbach's alpha $=$ $0.90 ; \mathrm{M}=2.18 ; \mathrm{SD}=0.78$ ).

- The ATO respects the individual's rights as a citizen

- The ATO is concerned about protecting the average citizen's rights

- The ATO considers the concerns of average citizens when making decisions

- The ATO cares about the position of taxpayers

- The ATO tries to be fair when making their decisions

- The ATO treats people with dignity and respect

\section{Stigmatization.}

Items measured on a $1=$ strongly disagree to $5=$ strongly agree scale (Cronbach's alpha $=$ $0.90 ; \mathrm{M}=3.70 ; \mathrm{SD}=1.00$ ).

- Did you feel as though you were treated as a bad person?

- Did you feel you were treated as though you were likely to commit another offence?

- Did you feel as though negative judgements were made about what kind of person you are?

- Did you feel as though you were treated as a criminal?

\section{Resentment toward Authority.}

Items measured on a $1=$ definitely not to $5=$ definitely yes scale (Cronbach's alpha $=0.79$; $\mathrm{M}=3.64 ; \mathrm{SD}=1.09$ ).

- Do you think the schemes situation has left you feeling bitter towards the ATO?

- Do you think the schemes situation has left you feeling bitter towards the Government?

\section{Resentment toward Taxpaying.}

Items measured on a $1=$ definitely not to $5=$ definitely yes scale (Cronbach's alpha $=0.67$; $\mathrm{M}=2.65 ; \mathrm{SD}=1.06$ ).

- Do you think the schemes situation has left you feeling bitter about paying tax? 
- $\quad$ Do you think your scheme-related experience has affected your taxpaying behaviour in a negative way?

\section{Tax Non-Compliance.}

Items measured on a $1=$ strongly disagree to $5=$ strongly agree scale $($ Cronbach's alpha $=$ $0.79 ; \mathrm{M}=1.90 ; \mathrm{SD}=0.72$ ).

- I no longer declare all my income

- I now use the tax system in a negative way to recoup the financial losses I have incurred

- I am now more defiant towards the ATO

- I now look for ways to purposefully cheat the tax system

- I now look for many ways to recoup my financial losses 
